\title{
RESPONDING TO THE CALL FOR CLIMATE ACTION
}

\author{
DANIEL E. LANE* \\ Centre de recherche marine, Petit de Grat Campus, \\ Université Sainte-Anne, NS, and \\ Telfer School of Management, \\ University of Ottawa, ON
}

\begin{abstract}
Global calls for action on climate change have become more urgent in recent years. However, how to act to achieve climate sustainability remains elusive. The evidence is clear that governmental initiatives - global, national, and provincial - have not been able to coalesce into a meaningful strategy for climate sustainability. What is required is a shift in climate responsibility from governments to individuals and communities who think globally but are best able to act locally. To encourage the citizenry to act requires a science-based information and education whereby climate action is clearly defined along with the consequences of actions (or inaction). Education must include a climate curriculum as a mainstream subject in our schools. Using this approach, local community baselines of climate information, vulnerability, and adaptive capacity can be established. In enhancing their climate roles, governments' need to shift from carrying out mandates for climate response, to becoming auditors of carbon use in which citizens and businesses are given incentives to reduce carbon footprints. Finally, increased investments need to be directed to communities so that they can take more responsibility and be more prepared to live with climate change impacts. Governments also need to engage the community in participatory strategic long-term planning for adaptation to the changing climate.

Keywords: climate action, climate responsibility, institutional arrangements, science-based information, education legacy, strategic planning, community investment
\end{abstract}

\section{INTRODUCTION}

On September 23, 2019, led by a 16-year-old Swede, Greta Thunberg, Time magazine's Person of the Year 2019, massive demonstrations took place all around the world for climate change action in concert with the United Nations Climate Action Summit in New York City and the

* Author to whom correspondence should be addressed: Daniel.Lane@USainteAnne.ca 
Global Climate Strike(United Nations 2019). These recent worldwide protests $^{1}$ led by the youth of the world called for immediate global action on climate change (Global Climate Strike 2019). Evidently, it is not acceptable simply to acknowledge climate change, rather it is imperative that we do something about it and soon.

'Ay, there lies the rub' (from Hamlet). But what do we DO? How do we ACT? We may be willing to act, and we may even be willing to incur "abrupt and disruptive" change as many climate change activists insist (National Research Council 2013). However, the problem is twofold: (1) by default, climate action directives come from global institutions and national governments which have taken on the responsibility to act on our behalf; and (2) we have very little idea of the consequences of "mandated actions", nor do we know and understand the suite of appropriate actions or how to determine and evaluate them. More likely, "action" is interpreted as a tax paid to our governments that provide others with some undetermined and unclear capability to act. Under these circumstances, how can we be expected, as individual citizens, to know what to do? Global protests calling for "government action" only complicate the vague idea of doing the 'right thing'.

It has taken years to arrive at the current climate crisis situation. Temperature change associated with global warming is referred to with respect to "pre-industrial levels" 2 which, in turn, refers to the '1850 to 1900 baseline period' (King et al. 2017). This time period predates all those alive today. Similarly, our strategic forecasts to the end of the $21^{\text {st }}$ century are beyond the lifetimes of nearly every adult person now alive. Thus, whatever actions we take now, the proponents of those actions will not be in a position to observe the associated impacts. As such, we are behaving as proxies for future generations who must live with the consequences of our actions today.

1 There have been several global climate demonstrations in recent years - 2009 (Mobilization for Copenhagen), 2014 (People's Climate March), 2015 (Global Climate March), 2017 (People's Climate March), and the 2019 Global Climate Strike (Wikipedia 2019).

2 Paris Accord commitment, Article 2(a): "Holding the increase in the global average temperature to well below $2^{\circ} \mathrm{C}$ above pre-industrial levels and pursuing efforts to limit the temperature increase to $1.5^{\circ} \mathrm{C}$ above pre-industrial levels, recognizing that this would significantly reduce the risks and impacts of climate change" (UNFCCC 2015). 
Current approaches do not work. It can be argued that decisions made now are inconsequential to current citizens or constituents. This may be the reason why governments, led by politicians on finite mandates, are not capable of addressing the strategic consequences of climate change. Top-down government-led global initiatives are not able to overcome the political difficulties of achieving change to our existing systems that would alter our economic status quo and cause prolonged hardship. In response to yet another impressive mobilization of global demonstrations on climate, The Economist (2019) recently reported:

"The [September 2019 New York United Nations Climate Action] Summit concluded with a torrent of announcements. There was a commitment by 65 countries and the European Union to reach zero-net carbon emissions by $2050 \ldots$ Some announcements were promises of future announcements. Fully 59 countries said they would shortly be unveiling more ambitious commitments under the Paris agreement... Even if all the pledges are acted on, though, the gap between what the summit promised and what needs to be done remains a chasm... Between 1988 and 2015, 71\% of greenhousegas emissions came from fossil fuels sold by 100 energy giants... including Exxon-Mobil, Royal Dutch Shell and BP. The firms vowed to limit methane emissions and highlighted their investment into carbon capture and sequestration. But they also explained that they were continuing to develop new oil and gas fields... They are unlikely to stop unless demand drops off." (pp. 56-57)

Meanwhile, it is widely reported that the December 2019 negotiations at COP25, the Madrid Summit (previously the Chile Summit), broke down and the meetings ended without an agreement on the global carbon market rules designed to maintain the targets of the 2015 Paris Agreement (Keating 2019).

In the face of the damning and ever-mounting climate change evidence (UNEP 2019, IPCC 2019, 2018), we nevertheless appear unable to take actions that will enable us to adapt and have improved climate sustainability. Klein (2014) asks the question: "What is wrong with us?" and further suggests that we need an overhaul of our capitalist economy in favour of a more equitable green plan (Klein 2019).

All indicators show that Canada is a poor performer with respect to greenhouse gas (GHG) emissions and among the highest of all nations in emissions per capita (GERMANWATCH 2019). 
In December 2015, enthusiasm was high in Canada when the new Minister of Environment and Climate Change returned from COP21 after the Paris Accord was signed. With a new federal government in place, Canada embarked on an ambitious program of convincing its provinces to take up a federally devised carbon pricing scheme and targeted emissions reductions. However, from the outset, opposition among some provinces to the federal nation-wide carbon tax proposal scheme, and designated emissions targets, signaled that the anticipated national program would not happen. The recent $\mathrm{Ca}-$ nadian federal election (October 2019) solidified regional disparities and highlighted difficulties in arriving at national unity on issues of climate policy hand-in-hand with the planned expansion of new pipelines for Canada's oil distribution.

In Nova Scotia, renewal is promised on Climate Action but initiatives like the Municipal Climate Change Action Plan (MCCAP, Nova Scotia 2013) are now outdated. Efforts are underway to rewrite The Environmental Goals and Sustainable Prosperity Act with renewed targets for reduced emissions, and investments in efficient sources of renewable energy (Nova Scotia 2019). However, when these targets will be approved or how this will encourage "action" by Nova Scotia citizens or companies is not at all clear.

\section{DISCUSSION}

Shift the responsibility. The message we must take away from our ineffectiveness to date, is that governmental initiatives - global, national, provincial - simply do not work. The many historical, socioeconomic, and cultural differences negate all opportunities for global agreements to bring about "abrupt and disruptive" action on climate change.

According to Konrad and Thum (2014) the role of governments in climate change is defined as:

"Firstly, the government has to help in improving our knowledge... Secondly, the government has to provide the regulatory framework for insurance markets... and to induce citizens to the appropriate amount of self-protection, insurance premiums have to be differentiated according to local disaster risks. Thirdly, fostering growth helps coping with the consequences of climate change and facilitates adaptation." 
This role recognizes governments as facilitators to its citizenry - not as sole leaders and doers. There is an implied shift of responsibility from government departments (that claim responsibility for managing adaptation to climate change) to "citizens" and communities. It is up to the citizenry to act, e.g., by learning the risks to our families and communities. They need to understand the options, and then agree to pay the real cost of counteracting the risks. Actions by citizens are an important means of answering Klein's (2014) “civilizational wake-up call" that is realized with the engagement and empowerment of our communities which should, by necessity, "think globally, but act locally".

Governments work best when they provide incentives for the population to act, and when they facilitate actions by companies, communities, and individuals. Before we consider answers, we need to ask the question: Who is responsible for acting on climate change? The answer acknowledges that we, the citizenry, are all responsible for human-induced climate change and as a consequence, we are all obligated to act. Assuming carbon is the culprit, we are all responsible daily for our decisions to emit carbon. Yet, most of us do not know the consequences of decisions to drive our cars, take a plane trip, or operate our barbeques. In order to know how to act, we need to be made more clearly aware of these consequences.

Establish an education legacy. It is important for groups like the NSIS to invest in developing education programs to inform people of the impacts of our carbon use as citizens of a globally leading country in per capita GHG emissions. We need to understand how we generate, use and measure carbon before we can begin to make decisions as to how we can reduce our use and curb our emissions (Wells 2018, 2019). Climate change is no longer a discipline reserved for meteorologists, climatologists, and natural scientists. Rather, there is an increasing need for interdisciplinary analysis that embraces all disciplines in a manner that can be measured and easily understood by the general public. Only this will lead to actions and consequences that result in reducing carbon emissions.

In Nova Scotia, The Environmental Goals and Sustainable Prosperity Act should recognize and expand educational efforts to disseminate climate change issues to primary, secondary, and post secondary NS education institutions. Nova Scotia school curricula embedded in the 
Grade 4 and Grade 11 provincial "Oceans 11" course should include extensive discussion on the science of climate change and climate action, and become mainstream - not optional.

\section{The Role of Governments - 'I think I'd better think it out again!'} (Fagin from the musical Oliver). Enlightened understanding, spurred by education based on science, stimulates the ways and means to act. In 2007, Gore (2007) argued in Inconvenient Truth that if appropriate 'actions' were taken soon, the effects of global warming can be successfully reversed by releasing less $\mathrm{CO}_{2}$ and planting more vegetation to consume existing $\mathrm{CO}_{2}$. Gore calls on individuals to help combat global warming by: recycling, speaking up in your community, buying a hybrid vehicle and encouraging everyone to watch his movie. While collectively, these actions by individuals are important, they are hardly "abrupt and disruptive". Surely, today, the urgency now exists that compels us to do much more than this. Herein lies the role of governments - to compel us as individuals to act.

\section{Much needed actions include:}

\section{Audit Individuals' Carbon Footprints}

As a first step in improved understanding, governments should implicate the citizenry by developing a carbon audit and an associated user pay tax based on our carbon footprints (Berners-Lee 2010). To do so requires a "carbon calculator" that would determine the total amount of greenhouse gases generated by our actions that include improving energy efficiency construction in homes and businesses, reducing heating energy costs, efficient lighting and appliances use, reduced water consumption, and enhanced composting and recycling practices ${ }^{3}$. The example of the Government of Newfoundland and Labrador, Department of Municipal Affairs and Environment's

\footnotetext{
"A carbon footprint is the total amount of greenhouse gases (including carbon dioxide and methane) that are generated by our actions. The average carbon footprint for a person in the United States [as well as Canada] is 16 tons, one of the highest rates in the world. Globally, the average is closer to 4 tons. To have the best chance of avoiding a $2^{\circ} \mathrm{C}$ rise in global temperatures, the average global carbon footprint per year needs to drop under 2 tons by 2050. Lowering individual carbon footprints from 16 tons to 2 tons doesn't happen overnight! By making small changes to our actions, like eating less meat, taking less connecting flights and line drying our clothes, we can start making a big difference." (Nature Trust 2019)
} 
carbon calculator "Turn back the tide" (Newfoundland and Labrador 2016) provides an excellent template for a more refined household audit framework that could be adopted by Nova Scotia, and indeed other provinces, as a key element of the new Environmental Goals and Sustainable Prosperity Act.

\section{Establish new institutional arrangements}

In support of the carbon use auditing role, governments need to prioritize climate change and develop new institutional arrangements that define committed strategic financing to prioritize the future. This should go beyond political mandates and provide incentives that would encourage individuals, communities, and businesses to act (Lane et al. 2015).

In Nova Scotia, the proposed revision of The Environmental Goals and Sustainable Prosperity Act should declare itself as a policy specifically associated with Nova Scotia's Action Plan on climate change. The Act should establish a new institutional arrangement with dedicated funding directed at informing, facilitating, promoting, and financing action by its citizens on climate change. In recognition of its importance, a new provincial department should be established that is elevated to be of the same importance as the Federal Department of Environment \& Climate Change from the current secondary designation within the Department of Environment - Climate Change Unit.

\section{Be prepared and Plan Strategically}

A key role of the new institution would be to define community preparedness measures that take into account the uncertainties of climate emergency events and their physical, socioeconomic and cultural human impacts. Preparedness indicators include regularly exercising Emergency Operations Centre(EOC) personnel in sessions that simulate the community's response to climate emergency events that would engage and improve awareness of members of the community. Clearly specified community indicators and objectives reflect the environmental, socioeconomic, cultural, and institutional priorities of the community. These objectives are measurable indicators to be monitored and tracked as a sign of community action (Chung 2014).

The institution should take on the role of evaluator of alternative adaptation measures for the information of its citizenry, e.g., new 
designs for family housing with solar heating and improved insulation. Such proposals should be backed by the scientific method of problem solving, and the institution should support recommendations for climate action through the evaluation of proposed strategy options for analysis and review. The problem solving tools associated with adaptive management in conjunction with simulation and system dynamics are fundamental to strategic evaluation over the long term (Lane, et al. 2017).

\section{Invest in Communities}

With the assistance of community stakeholders, the institution should focus on improving the communities' information baselines. This information includes identifying and profiling community vulnerability, recognizing and evaluating community resilience, and community adaptive capacity. The exercise of profiling community status is preliminary to identifying community priorities, especially in the face of stochastic climate changes (Lane et al. 2013, Lane et al. 2017).

Governments need to assign responsibility for engagement and collaboration among multiple community partners by ceding authority to local communities, municipal and local authorities. Local authority and responsibility requires participatory, traditional, indigenous and direct communication that will inform, sensitize, and create ownership within the local population (Lane et al. 2013, Klein 2014).

Finally, municipal governments need to assert their place in climate change by forming participatory institutions to support the MCCAP programs. The Regional Municipality of Halifax (HRM) now has a climate adaptation plan (MCCAP, Nova Scotia 2013 but one which is dated). It has a template that should be used by all Nova Scotia municipalities. The MCCAP is a strategic, forward looking plan that aims to address all aspects of the climate problem for households and companies. The MCCAP also associates problems and challenges with the evaluation of adaptations and solutions to protect, retreat, and accommodate, using e.g., nature-based approaches for coastal communities facing subsidence, sea-level rise, and storm surge impacts (Dal News 2019). Finally, the MCCAP should ensure that we no longer simply replace existing and failing infrastructure (e.g., for water, sewage, roads, power) without planning strategically to take account of any increases in loading due to climate change or an anticipated demand for services with greater capacity into the future. 
Let's hope Gore (2007) is right when he suggests that if appropriate 'actions' are taken soon by all citizens, the effects of global warming may be successfully mitigated. In order to achieve this, Nova Scotia can become national leaders whereby its citizenry are induced to act based on a strong and clearly understood foundation in science, led by groups like the NSIS, via an improved information baseline on the repercussions of climate impacts and the consequences of inaction, financed by incentives supported by our governments which should act as auditors and facilitators in our ongoing daily adaptation climate decisions and actions. We cannot fail to act in the pursuit of climate adaptation for sustainability. If we do not take up the call to action now, the consequences will be paid by our children, grandchildren, and future generations. If we do not move forward now, they will never understand why we did not act sooner.

\section{REFERENCES}

Berners-Lee, M. (2010). How bad are bananas? The carbon footprint of everything. Greystone Books: D\&M Publishers, Inc., Vancouver, B.C. $231 \mathrm{p}$.

Chung, A. (2014). Emergency Preparedness and Response Planning: A Value Based Approach to Preparing Coastal Communities for Sea Level Rise. M.Sc. Thesis. University of Ottawa. Master's Programme in Systems Science. $109 \mathrm{p}+$ appendices.

Dal News. (2019). The Big Picture: The looming threat of rising sea levels - and what we can do about it. December. www.dal.ca/news/2019/12/12/ the-big-picture--the-looming-threat-of-rising-sea-levels---and-w.html (Accessed December 13, 2019).

GERMANWATCH. (2019). Climate Change Performance Index (CCPI), Country Reports - Canada. www.climate-change-performance-index.org/ country/canada (Accessed December 15, 2019).

Gibson, B. (2019). The Industrialized World Is Failing to Meet Paris Agreement Goals. The American Prospect. October. https://prospect.org/world/ climate-crisis-industrialized-world-failing-to-meet-paris-agreement/ (Accessed October 30, 2019).

Global Climate Strike. (2019). https://globalclimatestrike.net/\#news (Accessed October 9, 2019).

Gore, A. (2007). An Inconvenient Truth: The crisis of global warming. Viking: New York.

IPCC. (2018). Global warming of $1.5^{\circ} \mathrm{C}$. Summary for Policymakers. 48th Session of the IPCC, Incheon, Republic of Korea, 6 October. 33 p. 
IPCC. (2019). Summary for Policymakers. In: IPCC Special Report on the Ocean and Cryosphere in a Changing Climate [H.-O. Pörtner, D.C. Roberts, V. Masson-Delmotte, P. Zhai, M. Tignor, E. Poloczanska, K. Mintenbeck, M. Nicolai, A. Okem, J. Petzold, B. Rama, N. Weyer (eds.)]. In press.

Keating, D. (2019). Failure in Madrid as COP25 Climate Summit ends in Disarray. December 15. Forbes On-line. www.forbes.com/sites davekeating/2019/12/15/failure-in-madrid-as-cop25-climate-summit-endsin-disarray/\#1b0da43c3d1f (Accessed December 15, 2019).

King, A., Henley, B., \& Hawkins, E. (2017). What is a pre-industrial climate and why does it matter? The Conversation. On-line journal of the Academic Journalism Society. http://theconversation.com/what-is-apre-industrial-climate-and-why-does-it-matter-78601 (Accessed October 30, 2019).

Klein, N. (2014). This Changes Everything: Capitalism vs the Climate. Alfred A. Knopf, Toronto. 566 p.

Klein, N. (2019). On Fire: The (Burning) Case for the Green New Deal. Alfred A. Knopf, Toronto. 320 p.

Konrad, K. \& Thum, M. (2014). What is the role of governments in climate change adaptation? Oxford University Press. OUPBlog. July 23. https:// blog.oup.com/2014/07/government-adaptation-climate-change/ (Accessed December 216, 2019).

Lane, D.E., Beigzadeh, S., \& Moll, R. (2017). Adaptation Decision Support: An Application of System Dynamics Modeling in Coastal Communities. International Journal of Disaster Risk Science. 8: 374-389.

Lane, D.E., Mercer Clarke, C., Clarke, J., Mycoo, M., \& Gobin, J. (2015). Managing adaptation to changing climate in coastal zones. In Coastal Zones: Solutions for the 21st Century, Baztan, J., Chouinard, O., Jorgensen, B., Tett, P., Vasseur, L., Vanderlinden, J.P (eds.). Elsevier, Chapter 9, pp. 141-160, Rio+20 Working Group.

Lane, D.E., Mercer Clarke, C., Forbes, D.L., \& Watson, P. (2013). The Gathering Storm: Managing Adaptation to Environmental Change in Coastal Communities and Small Islands. In Forbes, D.L. and Hay, J.E(eds.) Sustainability Science: Special Issue - Small Islands. 8(3): 469-489, July.

Lane, D.E., Moll, R., Beigzadeh, S., Kuziemsky, C., O'Sullivan, T., Charles, A., \& Berkes, F. (2017). A System Model of Collaborative Community Response to Environmental Emergencies. International Journal of Climate Change: Impacts and Responses. 9(4): 1-29.

National Research Council. (2013). Abrupt Impacts of Climate Change: Anticipating Surprises. Washington, DC: The National Academies Press. https://doi.org/10.17226/18373 (Accessed October 31, 2019).

Nature Trust. (2019). Carbon Calculator. www.nature.org/en-us/getinvolved/how-to-help/consider-your-impact/carbon-calculator/ (Accessed October 31, 2019).

Newfoundland and Labrador. (2016). Turn Back the Tide: Individual Carbon Calculator. Department of Municipal Affairs and Environment. www.turnbackthetide.ca/tools-and-resources/individual-carbon-calculator. shtml (Accessed October 31, 2019). 
Nova Scotia. (2013). Municipal Climate Change Action Planning Regional Municipality of Halifax. HRM Energy \& Environment submission to: Service Nova Scotia and Municipal Relations. September. $67 \mathrm{p}+$ appendices. www.halifax.ca/sites/default/files/documents/about-the-city/energyenvironment/MunicipalClimateChangeActionPlanReport.pdf (Accessed October 30, 2019).

Nova Scotia. (2019). Sustainable Prosperity Act: consultation. https:// novascotia.ca/sustainable-prosperity-act-consultation/ (Accessed September 27, 2019).

The Economist. (2019). The Global Climate Strike. October 1-10. 56-57.

UNFCCC. (2015.) The Paris Agreement. https://unfccc.int/files/essential_background/convention/application/pdf/english_paris_agreement.pdf (Accessed December 16, 2019)

United Nations. (2019). UN Climate Action Summit 2019. New York City. September 23, 2019. www.un.org/en/climatechange/un-climatesummit-2019.shtml (Accessed October 9, 2019).

United Nations Environmental Programme. (2019). Emissions Gap Report 2019. November. 81p. ISBN: 978-92-807-3766-0. https:// wedocs.unep.org/bitstream/handle/20.500.11822/30797/EGR2019. pdf? sequence $=1 \&$ isAllowed=y (Accessed December 3, 2019).

Wells, P.G. (2018). Editorial. Climate change in the Maritimes - concerns and challenges. Proceedings of the Nova Scotian Institute of Science 49(2): 201-203.

Wells, P.G. (2019). Editorial. Nova Scotia's many environmental issues - facilitating scientific understanding and action on multiple fronts. Proceedings of the Nova Scotian Institute of Science. 50(1): 1-3.

Wikipedia. (2019). Climate Movement. https://en.wikipedia.org/wiki/ Climate_movement (Accessed October 31, 2019). 
